\title{
Lingual Hemanjioma: Olgu Sunumu
}

\author{
Lingual Hemangioma: Case Report
}

\section{Muzaffer Durmuş ${ }^{1}$, Ugur Karapınar ${ }^{2}$, Yalçın Bayram ${ }^{3}$, Şükrü Yııdırım}

${ }^{1}$ Bursa Asker Hastanesi, Plastik Cerrahi Servisi, Bursa, Türkiye

${ }^{2}$ Bursa Asker Hastanesi, KBB servisi, Bursa, Türkiye

${ }^{3}$ Erzurum Asker Hastanesi, Plastik Cerrahi Servisi, Bursa, Türkiye

${ }^{4}$ Bursa Asker Hastanesi, Patoloji Servisi, Bursa, Türkiye

\section{ÖZET}

Hemanjiomlar çocukluk yaş grubunda en sık görülen baş-boyun tümörlerindendir. Erişkinlerde görülme sıklığı giderek azalır. Baş-boyun bölgesinde daha sık görülmelerine rağmen oral kavitede oldukça nadirdir. $\mathrm{Bu}$ çalışmada lingual yerleşimli hemanjioma ait klinik bulgu ve olası komplikasyonlar literatür verileri eşliğinde sunulmuştur. Altmış üç yaşında bayan hasta dilde kitle şikayeti nedeniyle polikliniğimize başvurdu. Hastaya lokal anestezi altında eksizyonel biopsi uygulandı. Postoperatif evrede herhangi bir ciddi sorunla karşılaşılmadı. Histopatolojik incelemede kapiller kavernöz hemanjioma olarak rapor edildi.

Lingual hemanjiomlar hastalarda kozmetik deformite, rekürren hemoraji, konuşma ve çiğneme problemlerine yol açabilirler. Hemanjiomların tedavisinde farmakolojik ve cerrahi tedaviyi içine alan birçok tedavi seçeneği tanımlanmıştır. Ayırıcı tanıda Skuamoz hücreli karsinoma, Kaposi sarkoma, epulis, telenjiektazi, baziller anjiomatozis gibi benign lezyonlar ve piyojenik granülom düşünülmelidir. Sonuç olarak hemanjiomların tipine göre gerekli preoperatif hazırlık yapılıp cerrahi eksizyonun unblok olarak yapılmasını önermekteyiz. Ardından deneyimli oral patolog eşliğinde ayırıcı tanısının yapılarak nükse dair bulguların takibi oldukça önem arz eder.

Anahtar Sözcükler: Hemanjiom, lingual, cerrahi, rekürrens, intraoral

Geliş Tarihi: 10.12 .2012

Kabul Tarihi: 30.05 .2013

\section{ABSTRACT}

Hemangiomas are among the most common head and neck neoplasms encountered in the pediatric age group. They are less common in the adult group. Although they are common in the head and neck region, hemangioma of oral cavity is rare. In this study, we present a lingual hemangioma together with literature data of the clinical findings and possible complications. A 63-year-old female patient was admitted to our clinic with a lingual mass. The patient underwent excisional biopsy under local anesthesia. There was no complication at postoperative follow-up. Histopathological study revealed a capillary cavernous hemangioma. Lingual hemangiomas may pose distressing problems to the patients, producing cosmetic deformity, recurrent hemorrhage and functional problems in speech, deglutition, and mastication. Several pharmacological and surgical treatment options have been identified for the treatment of hemangiomas. Differential diagnosis can include squamous cell carcinoma, Kaposi sarcoma, benign lesion like bacillary angiomatosis, epulis, telangiectasia, and pyogenic granuloma. As a result, we recommend a preoperative preparation according to the type of hemangiomas and en bloc surgical excision. Later on, accompanied by an experienced oral pathologist, the differential diagnosis and follow-up for the recurrence is very important.

Key Words: Hemangioma, lingual, surgery, recurrence, intraoral

Received: 12.10 .2012

Accepted: 05.30 .2013

\section{Giriş}

Hemanjiomlar sıklıkla çocukluk yaş grubunda görülen baş-boyun tümörlerindendir. Ağız içinde hemanjiomlar nadir olmakla beraber intraoral yörede dil, dudak, bukkal mukoza ve sert damakta görülebilmektedir (1). Olguların \%95'i doğumdan sonraki ilk 6 ay içinde ortaya çıkar ve çoğu zaman herhangi müdahaleye gerek kalmadan 6-7 yaşına kadar spontan regresyona uğrarlar (2). İleri yaşta ortaya çıkan ve derin yerleşimli lezyonların spontan iyileşme intimalleri daha azdır $(3,4)$. Hemanjiomlar, cilt ve mukozal yüzeylerde daha sık görülmesine rağmen derin dokuları da tutabilir. Hemanjiomlar kapiller, kavernöz yada her ikisinin birlikte olduğu şekilde karşımıza çıkabilir. Mulliken ve Glowacki hemanjiomların hızlı hücre çoğalması (proliferasyon) gösteren damar tümörleri olduğunu belirtmişlerdir (5). Anjiogenetik etmenlerin bu nedenle hemanjiomların büyüme ve gerilemesinde etkili olduğu düşünülmektedir. Hemanjiomlardan farklı olarak damarsal malformasyonlar ise displastik yapılar olup endotel hücrelerin çoğalma özelliği yoktur (6-7).
Hemanjiomların klinik olarak ortaya çıkışı diffüz cilt lezyonu ya da oral kavite, farinks, parotis ya da herhangi anatomik bölgede kistik kitle tarzında olabilir (4). Cilt yerleşiminde fizik muayene ile tanı çoğu zaman kolayca konabilir. Baş-boyun bölgesinde derin dokularda yerleşim gösterdiğinde yumuşak kıvamlı, üzerindeki cilt veya mukozada mavimsimor renk değişikliği yapan, ağsı görünümde, görülebilirler (2). Baş-boyun hemanjiomlarına, bazen vücudun başka yerlerindeki hemanjiomlar eşlik edebilir (8). Hemanjiomlar, baş-boyun bölgesinde daha sık görülmelerine rağmen oral kavitede oldukça nadirdirler. Lingual hemanjiomlar ise hastalarda kozmetik deformite, rekürren hemoraji, konuşma ve çiğneme problemlerine yol açabilirler (9).

$\mathrm{Bu}$ çalışmada dilde kitle şikayeti ile başvuran ve lingual yerleşimli hemanjioma tanısıyla tedavi edilen hasta literatürler eşliğinde sunuldu. 


\section{OLGU SUNUMU}

Altmış üç yaşında bayan hasta dilde kitle şikayeti nedeniyle polikliniğimize başvurdu. İntraoral muayenesinde dil sol lateralinde $25 \times 35$ $\mathrm{mm}$ boyutlarında benign görünümde kitle saptandı (Resim 1). Kitle mavimor renkte ağsı görünümde ve üzeri mukoza ile örtülüydü. Hasta kitlenin yaklaşık iki yıl önce belirdiğini son birkaç aydır ise boyutunun giderek arttığııı, konuşma ve çiğnemesini zorlaştırdı̆̆ını ifade etmekteydi. Hastanın oral kavite, farinks, tonsil ve diğer muayene bulguları normaldi. Baş-boyun bölgesinde lenfadenopati saptanmadı.

Hasta midazolam ( $5 \mathrm{mg} / 5 \mathrm{ml}$ Dormicum ${ }^{\circledast}$, Roche, Germany) destekli lokal anestezi altında operasyona alındı. Kitlenin sınırları belirlendi ve en blok olarak eksize edildi. İnsizyon hattı kapatılıp hasta 24 saat süresince dilde gelişebilecek ödem, kanama gibi olası komplikasyonlar açısından yakın takip edildi. Postoperatif evrede ciddi sorunla karşılaşılmadı. Histopatolojik incelemede kapiller kavernöz hemanjioma olarak rapor edildi (Şekil1). Hastanın 6 aylık takibinde rekürrens gözlenmedi (Resim2).

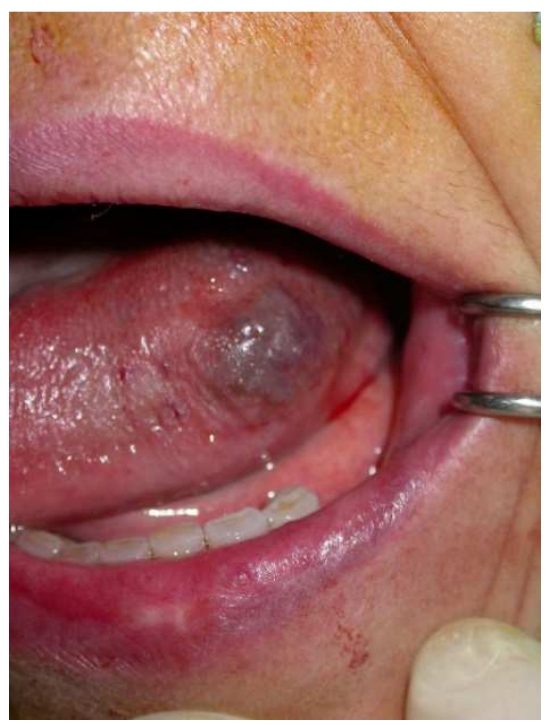

Resim 1. Dil sol laterali yerleşimli hemanjiom görülmektedir.

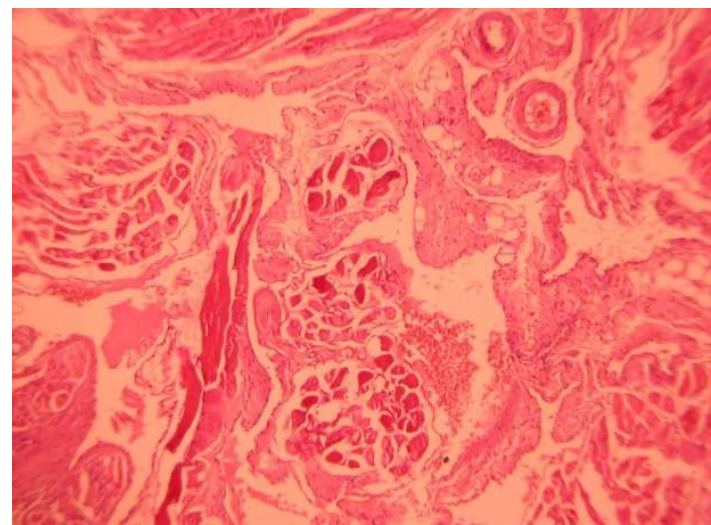

Şekil 1. Histopatolojik incelemede H\&E ile yapılan boyamada $50 x$ büyütmede değişik yönlerde seyreden çizgili kas demetleri arasında dilate vasküler yapılar görülmektedir.

\section{TARTIŞMA}

Hemanjiomlar, endotelyal hücrelerin benign bir proliferasyonu olarak kabul edilir. Baş-boyun bölgesinde sık görülmelerine rağmen oral kavitede oldukça nadirdirler (10). Sıklıkla neonatal dönemde oluşup, yaşamın ilk yılında büyüme gösterseler de yaşamın daha sonraki dönemlerinde spontan küçülme eğilimindedirler (11). Neonatal dönemde varolan ancak yaşamın daha sonraki dönemlerinde ortaya çıkan olgular literatürde bildirilmiş olup bunların spontan regresyonu bildirilmemiştir. Lingual yerleşimli hemanjiomlar, kozmetik deformite, rekürren hemoraji, konuşma ve çiğneme problemlerine yol açabilirler (9).

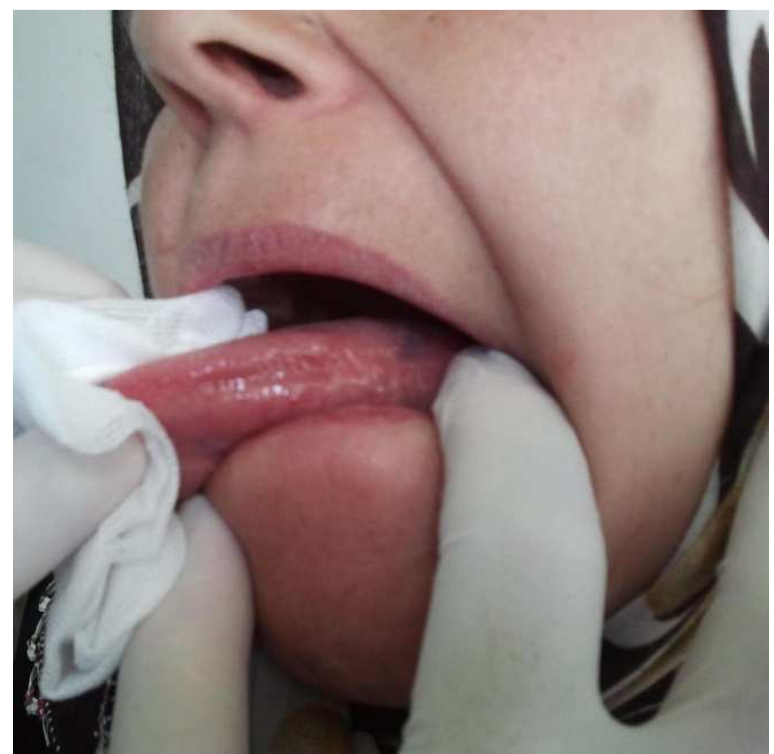

Resim 2. Hastanın postoperatif evre 6.aya ait görünümü izlenmektedir.

Ayırıcı tanıda skuamoz hücreli karsinoma, Kaposi sarkoma, epulis, telenjiektazi, baziller anjiomatozis gibi benign lezyonlar ve piyojenik granülom düşünülmelidir (11). Vasküler lezyonlar, hemanjiomlar ve vasküler malformasyonlar olarak sınıflandırılırlar. Vasküler anomaliler spontan regresyona uğramamaları, yumuşak kıvamda olmaları ve farklı biyolojik özellikleri nedeniyle hemanjiomlardan ayrılabilirler. Piyojenik granülom, hemanjioma ile klinik olarak sıklıkla karışabilen ve benzer histolojik özellikler (lobüler kapiller hemanjiom) gösteren bir lezyondur. Piyojenik granülom, çocuklarda da görülebilmesine rağmen genellikle erişkin bireylerde görülür. Yanak, gözkapağı ve ekstremiteler tipik tutulum bölgeleridir, ancak dudaklar, oral mukoza, dil ve nazal kavitede de nadiren görülebilir (3).

Hemanjiomların tedavisinde farmakolojik ve cerrahi tedaviyi içine alan birçok tedavi seçeneği tanımlanmıştır (10). En sık kullanılan tedavi metodu cerrahidir. Cerrahi eksizyon sonrası rekürens oranları değişmekle birlikte bazı yayınlarda yaklaşık yüzde \% 22,2 olarak bildirilmiştir. Kas dokusu içinde ve daha derin yerleşimli lezyonlarda rekürrens oranı daha fazla olmaktadır (12). Olgumuzda cerrahi eksizyon sonrası takip periyodunda herhangi sorunla karşılaşılmadı. Hastanın 6. ayında yapılan muayenesinde insizyon hattında nükse dair herhangi bir bulgu saptanmadı.

Hızlı büyüme paterni olan, solunum veya beslenme pasajını tıkayan, sıkça enfekte olan ya da kanayan hemanjiomlar aktif tedavi gerektirebilir ve tedavide en sık olarak kullanılan ajan steroidlerdir. Bazı hemanjiomlar steroide dramatik cevap verirler (12).

Hemanjiyomların tedavilerinin ardından nüks edebilecekleri belirtilmiştir $(9,13)$. Bu nedenle cerrahi operasyondan sonra hastalar düzenli aralıklarla kontrollere çağırılmalıdır. Sunulan olguda operasyon sonrasında ilgili bölgenin kontrollerinde tama yakın iyileşme gözlenmiş olup uzun dönemde takip için hastaya düzenli kontrollere gelmesi önerilmiştir.

Sonuç olarak, hemanjiomların takibi ve tedavi seçeneğinde hastanın yaşı ve lezyonun klinik özelliğini içeren faktörler kadar lezyonun hacmi ve büyümesi de dikkate alınmalıdır. Büyük boyutlara ulaşan ve/veya ülserasyon gösteren yüzeysel lezyonların, kanama ve estetik problemlere neden oluyorsa ve hastaya rahatsızlık veriyorsa eksize edilmeleri gereklidir. Ayrıca olgudaki gibi hemanjiyomların klinik özellikleri diğer bazı lezyonlarla benzerlik göstermeleri açısından dikkatli olunmalıdır. Bu nedenle tümörün klinik davranışının ve oluşabilecek komplikasyonların belirlenebilmesi için erken biyopsi ve tanı gereklidir.

\section{Çıkar Çatışması}

Yazarlar herhangi bir çıkar çatışması bildirmemişlerdir. 


\section{KAYNAKLAR}

1.Gill JS, Gill S, Bhardwaj A, Grover HS. Oral haemangioma. Case Report Med 2012;2012:347939.

2.Kutluhan A, Bozdemir K, Ugras S. The treatment of tongue hemangioma by plasma knife surgery. Singapore Med J 2008; 49: e312-4.

3.Rachappa MM, Triveni MN. Capillary hemangioma or pyogenic granuloma: A diagnostic dilemma. Contemp Clin Dent 2010;1:119-22.

4.Chahine KN, Tohme SM, Chouairy CJ. Cavernous hemangioma of the parotid gland. J Med Liban 2007;55:165-6.

5.Mulliken JB, Glowacki J. Hemangiomas and vascular malformations of infants and children, a classification based on endothelial characteristics. Plast Reconstr Surg 1982; 69: 412-22.

6.Pasyk KA, Cherry GW, Grabb WC, Sasaki GH. Quantitative evaluation of mast cells in cellularly dynamic and adynamic vascular malformations. Plast Recons Surg 1984; 73: 69-75.
7.Glowacki J, Mulliken JB. Mast cells in hemangiomas and vascular malformations. Pediatrics 1982; 70: 48-51.

8.Erdogan B, Sen O, Aydin VM, Yildirim T, Bircan S, Altinors N. Multi-organ cavernous hemangiomas: case report. Neurol Res 2003;25:92-4.

9.Bonet-Coloma C, Mínguez-Martínez I, Palma-Carrió C, Galán-Gil S, PeñarrochaDiago M, Mínguez-Sanz JM. Clinical characteristics, treatment and outcome of 28 oral haemangiomas in pediatric patients. Med Oral Patol Oral Cir Bucal 2011;16:e19-22.

10.Jafarzadeh H, Sanatkhani M, Mohtasham N. Oral pyogenic granuloma: a review. J Oral Sci 2006;48:167-75.

11.Canavese F, Soo BC, Chia SK, Krajbich JI. Surgical Outcome in Patients Treated for Hemangioma During Infancy, Childhood, and Adolescence: A Retrospective Review of 44 Consecutive Patient. J Pediatr Orthop 2008;28:381-6.

12.Zadok $D$, Levy $Y$, Nemet $P$. Regression of remote capillary haemangioma after local intralesional injection of corticosteroids. Eye(Lond) 1996;10:759.

13.Dilsiz A, Aydın T, Gürsan N. Capillary hemangioma as a rare benign tumor of the oral cavity: a case report. Cases J 2009;2: 8622 